Private Property and the Constitution 
This page intentionally left blank 


\title{
Private Property and the Constitution
}

\author{
Bruce A. Ackerman
}

New Haven and London, Yale University Press 
Published with assistance from the foundation established in memory of Calvin Chapin of the Class of 1788 , Yale College.

Copyright $\Theta 1977$ by Susan Rose-Ackerman, Trustee. All rights reserved. This book may not be reproduced, in whole or in part, in any form (beyond that copying permitted by Sections 107 and 108 of the U.S. Copyright Law and except by reviewers for the public press), without written permission from the publishers.

Library of Congress Cataloging in Publication Data Ackerman, Bruce A

Private property and the Constitution. Includes index.

1. Eminent domain-United States. 2. Property -United States. 3. United States-Constitutional law. I. Title.

$\mathrm{KF}_{5599 \cdot A 93} \quad 343^{\circ} \cdot 73^{\prime} 025 \quad 7^{6}-47^{667}$

ISBN: 978-0-300-02237-7 


\section{For \\ Alex Bickel, who taught me to disagree}


This page intentionally left blank 